\title{
Effect of Steaming on the Colorimetric Properties of Eucalyptus saligna Wood
}

\author{
Reinaldo Calçada Guina Luís ${ }^{1}$, Silvana Nisgoski², Ricardo Jorge Klitzke² \\ ${ }^{1}$ Departamento Engenharia Florestal, Universidade Eduardo Mondlane, Cidade de Maputo, Mozambique \\ ${ }^{2}$ Departamento de Engenharia e Tecnologia Florestal, Universidade Federal do Paraná - UFPR, Curitiba/PR, Brazil
}

\begin{abstract}
This study aimed to homogenize the color of Eucalyptus saligna wood by means of steaming and compare the resulting color with that of Cariniana legalis wood, a species of high commercial value. To this end, two steaming curves were tested: $100 \%$ relative humidity for 12 (T1) and 24 (T2) hours at $90^{\circ} \mathrm{C}$ followed by drying in a pilot-scale conventional kiln. The colorimetric parameters $\mathrm{L}^{\star}, \mathrm{a}^{\star}, \mathrm{b}^{\star}, \mathrm{C}^{\star}$, and $\mathrm{h}$ were determined according to the CIE $\mathrm{L}^{\star} \mathrm{a}^{\star} \mathrm{b}^{\star}$ color measurement system after drying. Results showed that steaming can be used for color homogenization between heartwood and sapwood. The treatment conducted for 24 hours (T2) presented the best results.
\end{abstract}

Keywords: wood colour, heat treatment, alternative species. 


\section{INTRODUCTION}

The presence of different shades of color between sapwood and heartwood on the same board of a wood species decreases its market value. This occurs in eucalyptus wood, which has been introduced as sawn wood on a larger scale in Brazil in recent years, generating material of low commercial value. The color of eucalyptus wood presents variable tonality, ranging from light beige to reddish pink.

Sapwood is usually lighter in color in species with reddish core. Color homogenization can be achieved by applying saturated steam before drying, making the wood homogeneous and similar to that from tropical species of higher market value, resulting in new application opportunities.

Color is one of the criteria to evaluate the characteristics of wood products, and it has been used as an index of classification and quality (Mori et al., 2004). The uniformity of wood color is an important factor in establishing the price and final value of the product (Möttönen et al., 2002).

Appreciation of a species can be conducted by analogy with others of traditional uses, which induces the use of terms of reference, such as "mahogany pattern", 'cherry pattern", and so forth (Camargos \& Gonçalez, 2001). Therefore, color becomes important because it is the first visual information, and it can immediately indicate the purpose of a particular product. In the case of wood, color is of great importance because it is part of its classification (Mori et al., 2005).

Visual color classification, however, is associated with personal impressions, resulting in a subjective evaluation. Accurate color analysis should be performed by quantitative methods using standard equipment (Mori et al., 2004). Several systems have been created to describe and quantify color to complement the chromaticity diagram proposed by the "Commission Internationale de L'Eclairage" (CIE). The CIELAB system, created in 1976, is applied to color measurements of wood and quantifies colors based on the following parameters: luminosity $\left(\mathrm{L}^{*}\right)$, chromatic coordinates $\left(a^{*}, b^{*}\right)$, and saturation $\left(C^{*}\right)$ (Hunt, 1995).

The application of wood steaming to promote color changes presents a potential that has been little explored by companies. The alternative of using this method to increase wood value is an idea that is in line with the current demands for applications of reforestation species. Therefore, this study aims to evaluate the effect of steaming on the homogenization of Eucalyptus saligna Smith wood color and compare the resulting color with that of jequitiba wood, a species of high commercial value.

\section{MATERIAL AND METHODS}

\subsection{Origin and preparation of samples}

Wood from Eucalyptus saligna trees aged 15 years were collected from MADEMAPE Wood Industry Ltda., located in the municipality of Campina Grande do Sul, Paraná state, Brazil. Sixty-six tangential boards obtained from the transition region between heartwood and sapwood of logs were selected. Each board was divided into three pieces with dimensions of $25 \times 100 \times 700 \mathrm{~mm}$ (thickness $\times$ width $\times$ length) (Figure 1(1)), and each of them corresponded to one treatment: T1 (12h), T2 (24h), and T (Control) (Figure 1(2)).

Two types of samples were extracted from each wood piece: two of them with dimensions of $20 \times 20 \times 100 \mathrm{~mm}$ (thickness $\times$ width $\times$ length), used for calculation of initial moisture content (sample A), and one with dimensions of $25 \times 100 \times 660 \mathrm{~mm}$ (thickness $\mathrm{x}$ width $\mathrm{x}$ length), for use in the treatments (sample B) (Figure 1(3)).

The " $\mathrm{A}$ " samples were weighed on a $0.01 \mathrm{~g}$ precision balance immediately after sectioning and were subjected to oven drying at $103 \pm 2{ }^{\circ} \mathrm{C}$ until constant weight was achieved. The dry basis moisture content of each wood

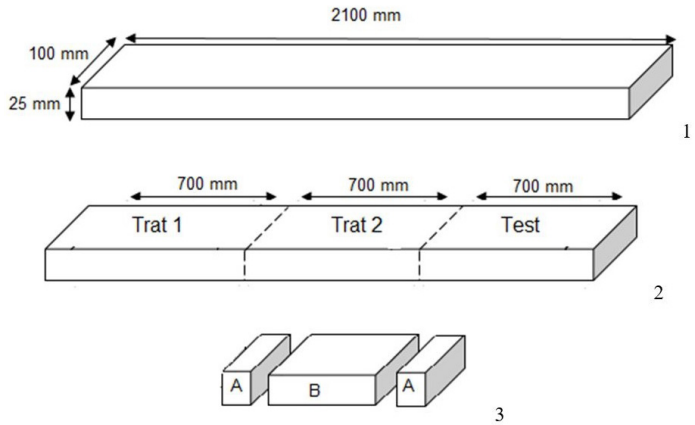

Figure 1. Eucalyptus saligna wood samples: Trat $1=$ Treatment $1(12 \mathrm{~h})$, Trat $2=$ Treatment $2(24 \mathrm{~h})$, and Test $=$ Control. (A) Moisture sample; (B) Treatment samples. 
load prior to steaming was determined using the mean of the two samples for each treatment and the control.

Each piece had three B samples that were randomly divided into three lots in a completely randomized design. In order to facilitate the interpretation of the results, colorimetric parameter analysis was performed by proposing three treatments with three replicates and comparing the means of these treatments.

\subsection{Steaming process}

The samples were stacked in the direction perpendicular to the airflow of the kiln, without separation between them, following the methodology adopted by Carvalho (2011). Two steaming times were used in the samples (Table 1), with constant temperature of $90^{\circ} \mathrm{C}$ and $100 \%$ relative humidity.

Both treatments (T1, 12h and T2, 24h) were conducted in a pilot-scale conventional kiln in the Wood Dry Laboratory at the Federal University of Paraná (UFPR). The difference between treatments is the remaining time in the stage that the temperature reaches $90^{\circ} \mathrm{C}$. This method was adapted from Carvalho (2011).

\subsection{Wood drying process}

After the steaming process, the samples were dried in a laboratory pilot-scale conventional kiln with nominal dimensions of $800 \times 1200 \times 4500 \mathrm{~mm}$ (width $\times$ height $\times$ length) and capacity for approximately $1 \mathrm{~m}^{3}$ of $25.4 \mathrm{~mm}$-thick lumber. The kiln operated in a heating system based on electric resistance, a humidification system using an electric boiler, and an air-circulation system capable of producing continuous airflow, adjustable by a frequency inverter to the desired air velocity.

The samples were stacked in the center of the kiln, in transversal direction of the airflow, on a drying cart, separated by battens with nominal dimensions of $25 \times 25 \times 1200 \mathrm{~mm}$ (width $\times$ thickness $\times$ length) which allowed free passage of air between the wood samples. The load was assembled on six layers with 11 boards each (Figure 2), forming a load with a height of approximately $300 \mathrm{~mm}$. A layer of dry boards and a wooden screen were placed on the wood load to direct the air only to the inside of the pile.
The drying program used in this study was adapted from Batista (2009) (Table 2). The airflow was adjusted by a frequency inverter at the output of the stack to approximately $2 \mathrm{~m} \mathrm{~s}^{-1}$, measured with a hot-wire thermometer.

\subsection{Colorimetric measures}

For each treatment, 20 boards were randomly selected from the 66 initial ones, resulting in 30\% for each lot. Samples were planed and cut on three faces

Table 1. Steaming time, temperature, and relative humidity of the treatments.

\begin{tabular}{cccc} 
Treatment & $\begin{array}{c}\text { Temperature } \\
\left({ }^{\circ} \mathbf{C}\right)\end{array}$ & $\begin{array}{c}\text { Relative } \\
\text { Humidity (\%) }\end{array}$ & $\begin{array}{c}\text { Time } \\
(\mathbf{h})\end{array}$ \\
\hline T1 & 90 & 100 & 12 \\
T2 & 90 & 100 & 24 \\
Control & $\mathrm{S}$ & $\mathrm{S}$ & $\mathrm{S}$ \\
\hline
\end{tabular}

$\mathrm{S}=$ Control without steaming.

Table 2. Drying program adapted from Batista (2009).

\begin{tabular}{|c|c|c|c|c|}
\hline \multirow{2}{*}{$\begin{array}{c}\text { Wood } \\
\text { Moisture } \\
\text { Content (\%) }\end{array}$} & \multicolumn{2}{|c|}{$\begin{array}{c}\text { Temperature } \\
\left({ }^{\circ} \mathrm{C}\right)\end{array}$} & \multirow{2}{*}{$\begin{array}{l}\text { Time } \\
\text { (h) }\end{array}$} & \multirow{2}{*}{$\begin{array}{c}\text { Dry } \\
\text { Potential }\end{array}$} \\
\hline & $\begin{array}{l}\text { Dry } \\
\text { bulb }\end{array}$ & $\begin{array}{l}\text { Wet } \\
\text { bulb }\end{array}$ & & \\
\hline Heating & 40 & 40 & 3 & - \\
\hline 45 & 40 & 38 & - & 2.5 \\
\hline 35 & 44 & 41 & - & 2.2 \\
\hline 31 & 46 & 42 & - & 2.2 \\
\hline 28 & 50 & 45 & - & 2.0 \\
\hline 25 & 54 & 48 & - & 2.1 \\
\hline 20 & 58 & 49 & - & 2.0 \\
\hline 17 & 60 & 49 & - & 2.1 \\
\hline 15 & 62 & 49 & - & 2.1 \\
\hline 12 & 66 & 51 & - & 2.0 \\
\hline 10 & 66 & 47 & - & 2.0 \\
\hline Standardization & 64 & 56 & 8 & - \\
\hline Conditioning & 62 & 56 & 8 & - \\
\hline Cooling & 44 & 35 & 4 & - \\
\hline
\end{tabular}

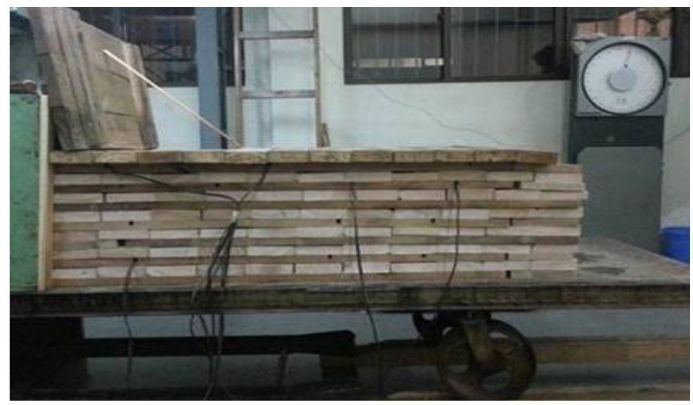

Figure 2. Load formation on the drying cart. 
(width, thickness, and length) and then stored in the dark until moisture equilibrium was reached (12 to 15\%).

Twenty measures were obtained for each sample, 10 in width, five in thickness, and five in the transversal section, in the Wood Anatomy Laboratory of the UFPR, using a Konica Minolta CM-5 spectrophotometer with a 400-750 nm spectral range, D65 light source, and $10^{\circ}$ observation angle (CIELab standard).

\subsection{Statistical analysis}

Colorimetric parameters were assessed by Analysis of Variance (ANOVA) of the three treatments and three replicates, considering statistical significance in the $\mathrm{F}$ test at $p \leq 0.05$. Subsequently, the Tukey test was applied to compare the means at a $5 \%$ level of significance.

\section{RESULTS AND DISCUSSION}

Changes in color were visible on Eucalyptus saligna wood samples as a result of steaming treatments. The visual differences in each treatment were perceptible, and it was noted that, in general, treated wood samples showed more homogeneous reddish color than that of the control.

The colors corresponding to the groups of values of the colorimetric parameters $\mathrm{L}^{*}, \mathrm{a}^{*}$, and $\mathrm{b}^{*}$ obtained for each treatment were identified based on the classification of color groups presented by Camargos \& Gonçalez (2001) (Table 3). It is worth noting that the pre-steaming of the samples somehow influenced their final color, and it was possible to verify that the original color of the samples was changed.

Values for the chromatic coordinates $\mathrm{a}^{\star}$ and $\mathrm{b}^{\star}$ from control and treatments were positive, leading to the classification of the samples in the first quadrant of the CIELAB colorimetric system, the expected behavior pattern for wood coloration (Camargos, 1999). The standard deviation was, in general, very homogeneous, showing uniformity of values of the samples analyzed.

The colorimetric parameters presented significant differences in all the treatments. It was observed that the steaming times $\left(12\right.$ and $24 \mathrm{~h}$ ) at $90^{\circ} \mathrm{C}$ and $100 \%$ relative humidity changed the levels of luminosity and reddish pigmentation of the wood. According to Pincelli (1999), increased temperature and treatment duration results in darker and more homogeneous wood coloration.
As for the chromatic coordinate $\mathrm{a}^{\star}$ (red spectrum), it was observed that the control presented lower values compared with those of treatments 1 and 2, and the redder wood was observed in treatment 2. Moura \& Brito (2011) and Pincelli (1999) found similar values for the $\mathrm{a}^{*}$ coordinate using the same temperature in their study on Eucalyptus thermal treatment.

With respect to the chromatic coordinate $b^{*}$ (yellow spectrum), it was observed that the control presented higher values in relation to those of treatments 1 and 2, making the wood yellower. Yellow coloration is associated with the presence of lignin and organometallic complexes in the extractives. Untreated wood is reported to have quinonoids and stilbene structures in its lignin, which confers some of its yellow hue (Falkehag et al., 1966). According to Moura \& Brito (2011), heat treatment interferes with the structure and/or quantity of these compounds in wood, thus altering its coloration.

The evaluation of reflectance curves of the width face (Figure 3 ) revealed that the values in the treatment 2 were lower in relation to the parameter $L^{*}$ (clarity),

Table 3. Mean values and standard deviation of the colorimetric parameters assessed in the width of the boards.

\begin{tabular}{cccc|} 
Parameter & Control & Treatment 1 & Treatment 2 \\
\hline \multirow{2}{*}{$\mathrm{L}^{*}$} & $69.41 \mathrm{a}$ & $63.04 \mathrm{~b}$ & $60.98 \mathrm{c}$ \\
& $(3.8)$ & $(3.3)$ & $(3.3)$ \\
$\mathrm{a}^{*}$ & $10.19 \mathrm{a}$ & $12.45 \mathrm{~b}$ & $13.31 \mathrm{c}$ \\
& $(1.9)$ & $(1.9)$ & $(1.9)$ \\
\hline \multirow{2}{*}{$\mathrm{b}^{*}$} & $19.13 \mathrm{a}$ & $17.87 \mathrm{~b}$ & $17.51 \mathrm{c}$ \\
\hline Color & $(1.2)$ & $(1.2)$ & $(1.2)$ \\
\hline
\end{tabular}

Means with same letter in the same line do not present statistical differences by the Tukey test at $5 \%$ significance level $(p>0.05)$.

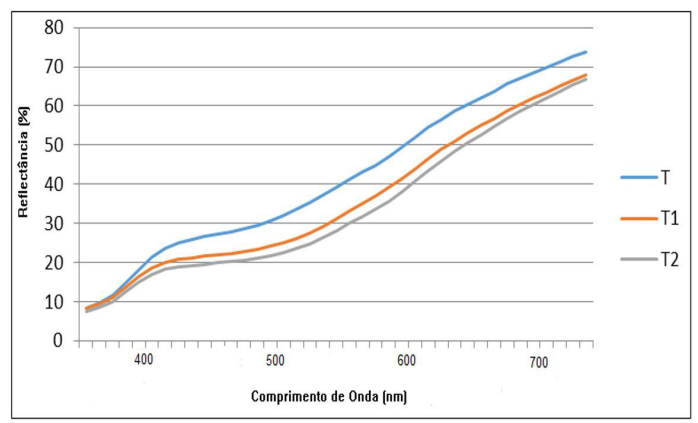

Figure 3. Reflectance curve of Eucalyptus wood in the width samples. (T) control; (T1) Treatment 1; (T2) Treatment 2. 
thus making the wood darker. This darkening may have been caused by the oxidative processes occurred in the components of the substances in the wood cells.

Luminosity $\left(\mathrm{L}^{*}\right)$ decreased with wood steaming time in the treatments (T1 and T2). Ratnasingam \& Grohmann (2013) obtained similar results when studying the steaming of rubberwood for 5,10 , and 15 hours. According to Griebeler (2013), as the temperature increases, wood luminosity decreases gradually. Esteves et al. (2008) verified a decrease in luminosity after treatment at $180^{\circ} \mathrm{C}$ for $24 \mathrm{~h}$ in Eucalyptus globulus wood.

When wood is submitted to thermal treatment, darkening of samples as a result of increased temperature generally occurs, as pointed out in the previous results reported by Pincelli (1999) and Moura \& Brito (2011).

Moura \& Brito (2011) reported that luminosity parameters present a negative correlation with total content of extractives. In addition, samples tended to be darker in color as the extractive content was reduced by the temperature. Bourgois et al. (1991) reported that wood luminosity reduction occurs in consequence of decrease in the extractive content caused by the temperature.

Treatments $\mathrm{T} 1$ and $\mathrm{T} 2$ resulted in greater wood homogenization with respect to the proportional reddish coloration in each piece compared with that of the control (Figure 4).

Treatment $\mathrm{T} 2$ presented the best results in relation to homogenization and reddish coloration, with steaming time of $24 \mathrm{~h}$. The more drastic the steaming condition, the better is the color homogenization. According to Alexiou et al. (1990), steaming time directly and proportionally influences color homogenization.

In Figure 5, the samples 40 and 29, both from T2 (24h), are compared with Cariniana legalis (jequitiba) wood, visually showing the possibility of value that steamed Eucalyptus wood can achieve with the change of its color.

Based on the comparison presented in Figure 5, it is possible to infer that wood steaming can be a favorable alternative to add value to aesthetically unattractive species that present good technological properties, to replace species of high market value or difficult to be obtained, as well as to preserve others already largely explored.

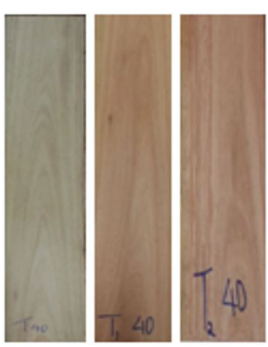

$\mathrm{T}(40) \mathrm{T} 1(40) \mathrm{T} 2(40)$

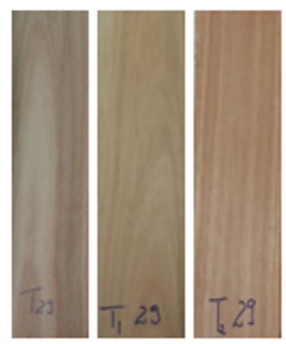

$\mathrm{T}(29) \mathrm{T} 1(29) \mathrm{T} 2$ (29)
Figure 4. Visual aspect of Eucalyptus saligna wood color: control (T); treatment 1 (T1); and treatment 2 (T2).

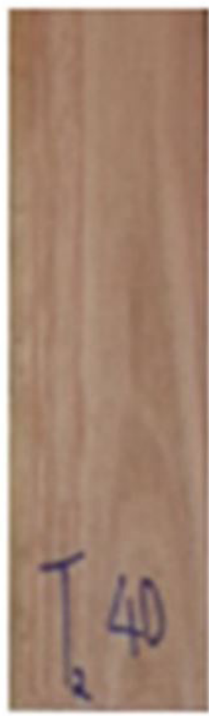

$\mathrm{T} 2-40$

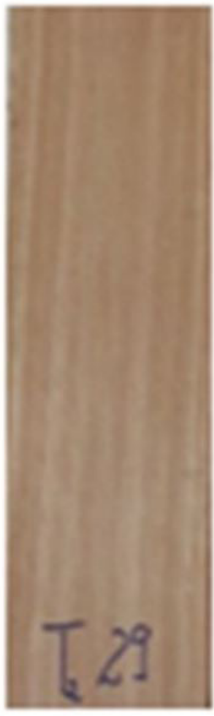

T2 -29

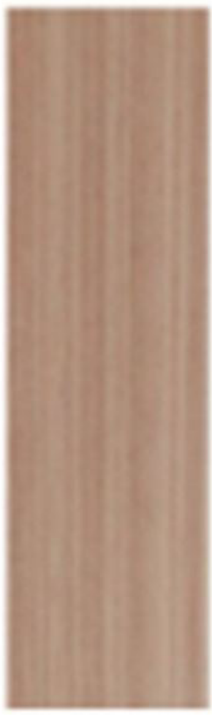

Cariniana

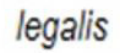

Figure 5. Visual aspect of Eucalyptus saligna wood color, treatment 2, compared with Cariniana legalis wood.

\section{CONCLUSIONS}

Steaming changes the colorimetric parameters of wood, mainly its luminosity, and proved to be able to lessen the difference between heartwood and sapwood color of Eucalyptus saligna, making it more reddish.

The longer steaming period, that is, the 24 -hour treatment (T2), showed better results regarding the homogenization of wood color. The steaming technique can be used to modify the coloration of Eucalyptus saligna wood in order to add value to the 
wood of this species. Steaming of Eucalyptus saligna wood samples for $24 \mathrm{~h}$ resulted in similar coloration to that of jequitiba (Cariniana legalis) wood, and it may have the same application as long as the purpose is aesthetic.

\section{SUBMISSION STATUS}

Received: 16 oct., 2014

Accepted: 10 may, 2017

\section{CORRESPONDENCE TO}

\section{Silvana Nisgoski}

Departamento de Engenharia e Tecnologia Florestal, Universidade Federal do Paraná UFPR, Av. Prefeito Lothário Meissner, 632, Jardim Botânico, CEP 80210-170, Curitiba, PR, Brazil

e-mail: nisgoski@ufpr.br

\section{REFERENCES}

Alexiou PN, Marchant JF, Groves KW. Effect of presteaming on moisture gradients, drying stresses and sets, and face checking in regrowth Eucalyptus pilularis Sm. Wood Science and Technology 1990; 24: 201-209.

Batista DC. Qualidade da secagem convencional conjunta da madeira de nove clones do gênero Eucalyptus. [dissertation]. Curitiba; Universidade Federal do Paraná; 2009.

Bourgois PJ, Guyonnet R, Janin G. La mesure de couleur: une méthode d'étude et d'optimisation des transformations chimiques du bois thermolysé. Holzforschung 1991; 45(5): 377-382. http://dx.doi.org/10.1515/hfsg.1991.45.5.377.

Camargos JAA. Colorimetria quantitativa aplicada na elaboração de uma tabela de cores para madeiras tropicais [dissertation]. Brasília: Universidade de Brasília; 1999.

Camargos JAA, Gonçalez JC. A colorimetria aplicada como instrumento na elaboração de uma tabela de cores de madeira. Brasil Florestal 2001; 71: 30-41.
Carvalho HJO. Desenvolvimento de metodologia para homogeneização de coloração de madeira de cerne e alburno de Eucalyptus grandis [monography]. Curitiba; Universidade Federal do Paraná; 2011.

Esteves B, Domingos I, Pereira H. Improvement of technological quality of eucalypt wood by heat treatment in air at $170-200^{\circ} \mathrm{C}$. Forest Products Journal 2008; $57(1 / 2)$ : 47-52.

Falkehag SI, Marton J, Adler E. Chromophores in Kraft lignin. In: Marton J, editor. Lignin structure and reactions. Washington: Ed. Marton; 1966.

Griebeler CGO. Colorimetria da Madeira de Eucalyptus grandis W. Hill. Ex Maiden modificada termicamente. [dissertation]. Curitiba; Universidade Federal do Paraná; 2013.

Hunt RWG. The reproduction of colour in photography, printing and television. 5th ed. Tolworth: Fountain Press; 1995.

Mori CLSO, Lima JT, Mori FA, Trugilho PF, Gonçalez JC. Caracterização da cor da madeira de clones de híbridos de Eucalyptus spp. Cerne 2005; 11(2): 137-146.

Mori CLSO, Mori FA, Lima JT, Trugilho F, Oliveira AC. Características tecnológicas na cor da madeira de eucaliptos. Ciência Florestal 2004; 14(2): 123-132. http:// dx.doi.org/10.5902/198050981812.

Möttönen K, Alvila L, Pakkanen T. CIELab measurements to determine the role of felling season, log storage and kiln drying on coloration of silver birch wood. Scandinavian Journal of Forest Research 2002; 17(2): 179-191. http:// dx.doi.org/10.1080/028275802753626827.

Moura L, Brito J. Efeito da termorretificação sobre as propriedades colorimétricas das madeiras de Eucalyptus grandis e Pinus caribaea var. hondurensis. Scientia Forestalis 2011; 39(89): 69-76.

Pincelli ALPSM. Efeito da termorretificação no envernizamento, colagem e cor da madeira de Eucalyptus saligna e Pinus caribaea var. hondurensis [dissertation]. Piracicaba: Escola Superior de Agricultura “Luiz de Queiroz", Universidade de São Paulo; 1999.

Ratnasingam J, Grohmann R. Effects of pre-steaming on the drying quality of Rubberwood. Berlin: Springer-Verlag; 2013. 